\title{
Novel Epoxy Activated Hydrogels for Solving Lactose Intolerance
}

\author{
Magdy M. M. Elnashar ${ }^{1,2,3}$ and Mohamed E. Hassan ${ }^{1,4}$ \\ ${ }^{1}$ Center of Excellence, Encapsulation \& Nanobiotechnology Group, National Research Center, El-Behouth Street, Cairo 12311, Egypt \\ ${ }^{2}$ Polymers Department, National Research Center, El-Behouth Street, Cairo 12311, Egypt \\ ${ }^{3}$ Biochemistry Department, Taif University, Taif, Saudi Arabia \\ ${ }^{4}$ Chemistry of Natural and Microbial Products Department, National Research Center, El-Behouth Street, Cairo 12311, Egypt
}

Correspondence should be addressed to Magdy M. M. Elnashar; magmel@gmail.com

Received 28 March 2014; Revised 10 May 2014; Accepted 13 May 2014; Published 11 June 2014

Academic Editor: Shirui Mao

Copyright (C) 2014 M. M. M. Elnashar and M. E. Hassan. This is an open access article distributed under the Creative Commons Attribution License, which permits unrestricted use, distribution, and reproduction in any medium, provided the original work is properly cited.

\begin{abstract}
"Lactose intolerance" is a medical problem for almost $70 \%$ of the world population. Milk and dairy products contain 5-10\% w/v lactose. Hydrolysis of lactose by immobilized lactase is an industrial solution. In this work, we succeeded to increase the lactase loading capacity to more than 3-fold to $36.3 \mathrm{U} / \mathrm{g}$ gel using epoxy activated hydrogels compared to $11 \mathrm{U} / \mathrm{g}$ gel using aldehyde activated carrageenan. The hydrogel's mode of interaction was proven by FTIR, DSC, and TGA. The high activity of the epoxy group was regarded to its ability to attach to the enzyme's $-\mathrm{SH},-\mathrm{NH}$, and $-\mathrm{OH}$ groups, whereas the aldehyde group could only bind to the enzyme's $-\mathrm{NH}_{2}$ group. The optimum conditions for immobilization such as epoxy chain length and enzyme concentration have been studied. Furthermore, the optimum enzyme conditions were also deliberated and showed better stability for the immobilized enzyme and the Michaelis constants, $K_{m}$ and $V_{\max }$, were doubled. Results revealed also that both free and immobilized enzymes reached their maximum rate of lactose conversion after $2 \mathrm{~h}$, albeit, the aldehyde activated hydrogel could only reach $63 \%$ of the free enzyme. In brief, the epoxy activated hydrogels are more efficient in immobilizing more enzymes than the aldehyde activated hydrogel.
\end{abstract}

\section{Introduction}

Lactases ( $\beta$-galactosidases) are indeed important enzymes in food industry and have found significant applications in enhancing sweetness, solubility, flavor, and digestibility of dairy products [1]. A major application of $\beta$-galactosidase is lactose hydrolysis, a process that results in the formation of glucose and galactose. Lactose is the major sugar (4$5 \%)$ present in milk. The consumption of foods with a high content of lactose is causing a medical problem for almost $70 \%$ of the world population, especially in the developing countries, as the naturally present enzyme in the human intestine loses its activity during lifetime, so its hydrolysis makes milk fit for consumption of lactose intolerant people [2]. Hydrolysis of lactose present in milk using enzymes such as lactases will produce lactose-free milk and lactose-free dairy products [3]

In industries, immobilized enzymes are preferred over the free ones. The immobilization technique would enable the reusability of enzymes for tens of times, reducing the enzyme and product cost significantly. Unfortunately, efficient commercial carriers suitable for immobilization of enzymes are relatively expensive $[4,5]$. Understandably, for food, pharmaceutical, medical, and agricultural applications, nontoxicity, and biocompatibility of the materials are also required. Among many carriers that have been considered and studied for immobilizing enzymes, organic or inorganic, natural or synthetic, chitosan and carrageenan are of interest in that they offer most of the above characteristics and are available at a reasonable cost [3].

Chitosan is a cationic naturally occurring polymer obtained from the deacetylation of chitin, which is the second most abundant polymer in nature after cellulose $[6,7]$. Chitosan has an abundance of amino groups (70-95\%), that make chitosan a cationic polyelectrolyte $(\mathrm{pKa} \approx 6.5)$ and one of the few found in nature. This basicity gives chitosan singular properties: chitosan is soluble in aqueous acidic media at 
$\mathrm{pH}<6.5$ and when dissolved possesses high positive charge on $\mathrm{NH}_{3}{ }^{+}$groups. The protonated $\left(\mathrm{NH}_{3}{ }^{+}\right)$could adhere to negatively charged surfaces such as polyanionic compounds $[8,9]$.

Carrageenan is a naturally occurring anionic polysaccharide isolated from the seaweeds. According to the study made by Chao et al., 1986 [10], to harden the carrageenan gels using different amine compounds, they concluded that only polyamines such as chitosan substantially improved the carrageenan gels thermal stability via polyelectrolyte's interactions. Unfortunately, the carrageenan-polyelectrolyte systems were limited to the entrapment of enzymes [1113 ], which have the major problem of enzyme leakage. For example, Boadi and Neufeld, 2001 [14], used alginate and carrageenan to entrap tannase and then crosslinked the gel beads with chitosan followed by glutaraldehyde. The entrapment technique limits their industrial use as supports for enzyme immobilization due to enzyme leakage. So, efforts to immobilize enzymes on newer type of carriers, especially with covalent bonds, are still underway in many laboratories [15-18].

To our knowledge, previous reports have not any greater extent that dealt with carrageenan-chitosan polyelectrolyte as a use for the covalent immobilization of enzymes, with an exception of our recent work $[19,20]$. In that work, we immobilized $\beta$-galactosidase covalently via its amino groups to carrageenan treated with chitosan and glutaraldehyde. Although the linkage was covalent, however, the enzyme loading capacity was limited to up to $11 \mathrm{U} / \mathrm{g}$ gel beads. This could be regarded to the free aldehyde groups on the carrageenan treated chitosan that could only react with the free amino groups $\left(\mathrm{NH}_{2}\right)$ on the enzyme via Schiff's base formation, $-\mathrm{C}=\mathrm{NH}-[19,20]$.

Thus, the purpose of this research was to modify the carrageenan with chitosan and a more efficient functional group, epoxy group, which imparts three extra benefits to carrageenan:

(i) the first is improvement of the carrageenan gel's thermal stability by forming a polyelectrolyte complex (PEC) between the carrageenan $-\mathrm{OSO}_{3}{ }^{-}$and the chitosan $-\mathrm{NH}_{3}{ }^{+}$;

(ii) the second is creation of a new functionality, free chitosan amino groups $\left(\mathrm{NH}_{2}\right)$;

(iii) the third is activation of the free chitosan amino groups $\left(-\mathrm{NH}_{2}\right)$ with 1,4-butanediol diglycidyl ether to impart free epoxy groups to covalently immobilize $\beta$-galactosidase via the $-\mathrm{SH},-\mathrm{OH}$, and $-\mathrm{NH}$ of their amino acids.

Accordingly, we expect more enzymes to bind to the epoxy activated carrier via three groups on the enzyme $(-\mathrm{SH},-\mathrm{OH}$, and $-\mathrm{NH})$, whereas the free aldehyde groups could only bind to the $-\mathrm{NH}_{2}$ of the amino acids. To our knowledge, there are no reports on the use of carrageenan for the immobilization of $\beta$-galactosidase using covalent technique via chitosan and 1,4-butanediol diglycidyl ether. The novel gel formulation was prepared in beads shape using the Encapsulator to enable gel beads production on the semipilot scale and to increase the gel's surface area. The grafted formulation was illustrated using a schematic diagram and the chemical and thermal modification was proved using the FTIR and DSC techniques, respectively. On the other hand, the enzyme loading capacity was optimized by using short and long chain of the epoxy activated carrier and using different concentrations of the enzyme. Finally, the free and immobilized enzymes were characterized for their activities at different $\mathrm{pHs}$ and temperatures and the Michaelis constants were studied as well as the lactose hydrolysis using free and immobilized enzyme over time.

\section{Materials and Methods}

As a general rule, all experiments were carried out in triplicate and data are means $\pm \mathrm{SD}(n=3)$. The abbreviations section is listing all the abbreviations used in the formulations samples.

2.1. Materials. $\mathcal{\kappa}$-Carrageenan (MW: 154,000), sulfate ester 25 , and chitosan were supplied by Fluka. $\beta$-Galactosidase (EC 3.2.1.23) was obtained from Aspergillus oryzae and $11.8 \mathrm{U} / \mathrm{mg}$ was obtained from Sigma-Fluka-Aldrich. All other chemicals were of pure grades (Analar or equivalent quality). The Encapsulator, model IE-50, was purchased from Innotech Encapsulator in Switzerland. The gel disks dimensions were measured using a micrometer (Micro 2000, 0-25 mm).

2.2. Determination of $\beta$-Galactosidase Activity. $\beta$-Galactosidase activity was determined by the rate of glucose formation in the reaction medium. Known amount of immobilized or free enzyme was incubated into $10 \mathrm{~mL}$ of $200 \mathrm{mM}$ lactose solution in $100 \mathrm{mM}$ citrate phosphate buffer at $\mathrm{pH} 4.5$ for $3 \mathrm{~h}$ at $37^{\circ} \mathrm{C}$ and $100 \mathrm{rpm}$. At the end of the time, $50 \mu \mathrm{L}$ of reaction mixture was added to $950 \mu \mathrm{L}$ buffer and boiled for $10 \mathrm{~min}$ to inactivate the enzyme and analyzed for glucose content using the glucose test. One enzyme unit (IU) was defined as the amount of enzyme that catalyzes the formation of $1 \mu \mathrm{mol}$ of glucose per minute under the specified conditions.

Equations (1), (2), and (3) show the hydrolysis of lactose by $\beta$-galactosidase and glucose determination using a mixture of enzymes, glucose oxidase (GOD), and peroxidase (POD):

$$
\begin{gathered}
\text { Lactose } \stackrel{\beta \text {-galactosidase }}{\longrightarrow} \text { Glucose }+ \text { Galactose } \\
\text { Glucose }+\mathrm{O}_{2}+\mathrm{H}_{2} \mathrm{O} \stackrel{\text { GOD }}{\longrightarrow} \text { Glucolactone }+\mathrm{H}_{2} \mathrm{O}_{2} \\
\mathrm{H}_{2} \mathrm{O}_{2}+\text { Hydroxybenoate-Na-4-aminoantipyrine } \\
\stackrel{\text { POD }}{\longrightarrow} \text { Quinon complex }+\mathrm{H}_{2} \mathrm{O}
\end{gathered}
$$

Glucose concentration was measured spectrophotometrically with a glucose test based on the Trinder reagent. Glucose is transformed to gluconic acid and hydrogen peroxide by glucose oxidase (GOD). The hydrogen peroxide formed reacts in the presence of peroxidase (POD) with 4aminoantipyrine and $\mathrm{p}$-hydroxybenzene sulfonate to form a quinoneimine dye, as shown in Equations (1), (2), and (3). 
The intensity of the color produced is directly proportional to the glucose concentration in the sample. The assay was performed by mixing $30 \mu \mathrm{L}$ of a sample of unknown concentration and $3 \mathrm{~mL}$ of Trinder reagent; the reaction was allowed to proceed for $20 \mathrm{~min}$ at room temperature, and the absorbance of the unknown concentration was read at $510 \mathrm{~nm}$ [19].

2.3. Preparation of Gel Beads. $\kappa$-Carrageenan gel was prepared by dissolving $2.5 \%(\mathrm{w} / \mathrm{v})$ carrageenan in distilled water at $70^{\circ} \mathrm{C}$ using an overhead mechanical stirrer until complete dissolution had occurred. The Carrageenan gel solution was dropped through a nozzle of $300 \mu \mathrm{m}$ using the Innotech Encapsulator in a hardening solution of $0.3 \mathrm{M} \mathrm{KCl}$. Then, beads were hardened using $0.3 \mathrm{M} \mathrm{KCl}$ for $3 \mathrm{~h}$.

2.4. Modification of Gel Beads Using Chitosan and Epoxy. Two activated epoxy hydrogels were prepared, the short and the long chain, as follows.

(a) The Short Chain. Carr.-Ch.-Epo: beads were soaked in a solution of $0.75 \%$ chitosan previously prepared in $1 \%$ (v/v) acetic acid. Then, they were suspended in $75 \mathrm{~mL}$ $0.5 \mathrm{M} \mathrm{NaOH}$ containing $150 \mathrm{mg}$ sodium cyanoborohydride under stirring. Slowly $75 \mathrm{~mL} \mathrm{1,4-butanediol}$ diglycidyl ether was added with constant stirring and the reaction was left at room temperature overnight. Finally, the activated gel beads were extensively washed with water to remove excess reagent.

(b) The Long Chain. Carr.-Ch.-Epo.-Ch.-Epo: formula (a) was further modified with chitosan and then epoxy as shown above.

2.5. Elucidation of the Modified Gel Using Fourier Transform Infrared Spectroscopy. The infrared spectra of all formulations were recorded with Fourier transform infrared spectroscopy (FTIR-8300, Shimadzu, Japan). FTIR spectra were taken in the wavelength region 4,000 to $400 \mathrm{~cm}^{-1}$ at ambient temperature. The FTIR spectrophotometer (FTIR8300 , Shimadzu, Japan) was used to prove the presence of the new functional group, epoxy groups, in both forms of the modified gels. Five samples were used for this test: carrageenan (Carr.); carrageenan coated with chitosan (Carr.Ch.); carrageenan coated with chitosan followed by epoxy (short chain epoxy activated hydrogel: Carr.-Ch.-Epo.); carrageenan coated with chitosan followed by epoxy followed by chitosan (Carr.-Ch-Epo.-Ch.); and, finally, carrageenan coated with chitosan followed by epoxy followed by chitosan followed by epoxy (long chain epoxy activated hydrogel: Carr.-Ch-Epo.-Ch.-Epo.).

A total of $2 \%(\mathrm{w} / \mathrm{w})$ of the sample, with respect to the potassium bromide (KBr; S. D. Fine Chem, Ltd.) disk, was mixed with dry $\mathrm{KBr}$. The mixture was ground into a fine powder using an agate mortar before it was compressed into a $\mathrm{KBr}$ disk under a hydraulic press at 10,000 psi. Each $\mathrm{KBr}$ disk was scanned 16 times at $4 \mathrm{~mm} / \mathrm{s}$ at a resolution of $2 \mathrm{~cm}^{-1}$ over a wavenumber range of $400-4000 \mathrm{~cm}^{-1}$, using Happ-Genzel apodization.
2.6. Differential Scanning Calorimetry and Thermal Gravimetric Analysis. Differential scanning calorimetry (DSC) and thermal gravimetric analysis (TGAA) were performed to prove the formation of a strong polyelectrolyte complex between carrageenan and chitosan followed by di-epoxy. The thermal behavior of five gel formulations was performed: Carr.; Carr.-Ch; Carr.-Ch-Epo.; Carr.-Ch-Epo.-Ch.; Carr.Ch-Epo.-Ch.-Epo. The differential scanning calorimetry was studied using DSC (SDT 600, TA Instruments, USA). Approximately 3 to $6 \mathrm{mg}$ of the dried gels was weighed into an alumina pan. The samples were heated from $40^{\circ} \mathrm{C}$ to $340^{\circ} \mathrm{C}$ at a heating rate of $10^{\circ} \mathrm{C} / \mathrm{min}$. The thermal behavior of the different gel formulations was characterized for their TGA (SDT 600, TA Instruments, USA). Alumina pans were used and approximately 3 to $6 \mathrm{mg}$ of the dried gels were weighed. The samples were heated from 50 to $300^{\circ} \mathrm{C}$ at a heating rate of $10^{\circ} \mathrm{C} / \mathrm{min}$.

2.7. Immobilization of $\beta$-galactosidase. $\beta$-Galactosidase was immobilized onto the short and long chain of the epoxy activated hydrogels as follows. One gram of the activated gel beads was washed thoroughly with distilled water and was incubated into $10 \mathrm{~mL}$ of enzyme solution $(3.0 \mathrm{U} / \mathrm{mL})$ prepared in $100 \mathrm{mM}$ citrate-phosphate buffer at $\mathrm{pH} 4.5$ for $16 \mathrm{~h}$. The immobilized enzyme was washed thoroughly with the buffer solution containing Tris- $\mathrm{HCl}$ to block any free aldehyde group and to remove any unbound enzyme. The immobilized enzyme was stored at $4^{\circ} \mathrm{C}$ for further measurements. Two parameters were used to reach the enzyme's maximum loading capacity (E.L.C.) and epoxy activated long and short chains as well as the enzyme concentration.

The E.L.C. or the amount of enzymes' units immobilized onto and into gel beads was calculated as follows:

$$
\text { E.L.C. }=\frac{\left(M_{o}-M_{f}\right)}{W} \text {, }
$$

where $M_{o}$ is the initial enzyme activity $(\mathrm{U}), M_{f}$ is the enzyme activity of the filtrate (U) after immobilization, and $W$ is the weight of gel beads $(\mathrm{g})$.

\subsection{Optimization and Evaluation of the Free and Immobilized $\beta$-Galactosidase}

2.8.1. Temperature and $p H$ Profiles for the Free and Immobilized $\beta$-Galactosidase. The free and immobilized $\beta$ galactosidases were incubated into $10 \mathrm{~mL}$ of $200 \mathrm{mM}$ lactose at temperatures from $30^{\circ} \mathrm{C}$ to $70^{\circ} \mathrm{C}$ for $3 \mathrm{hrs}$. The enzyme activity has been determined according to Section 2.2. The optimum temperature has been chosen to study the effect of $\mathrm{pH}$ where the free and immobilized $\beta$-galactosidases were incubated into $10 \mathrm{~mL}$ of $200 \mathrm{mM}$ lactose at $\mathrm{pH} 3.0-9.0$ at $37^{\circ} \mathrm{C}$ for $3 \mathrm{hrs}$.

2.8.2. $K_{m}$ and $V_{\max }$ of the Free and Immobilized $\beta$ Galactosidase. The Michaelis-Menten kinetic models adequate for the description of the hydrolysis of lactose by the free and the immobilized enzyme; apparent $K_{m}$ and $V_{\max }$ 


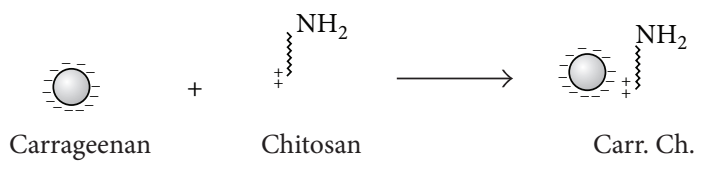

(a)

$$
\begin{aligned}
& \text { 1,4-Butanediol diglycidyl ether } \quad \text { Epoxy activated carrageenan } \\
& \text { Carr. Ch. }
\end{aligned}
$$

(b)

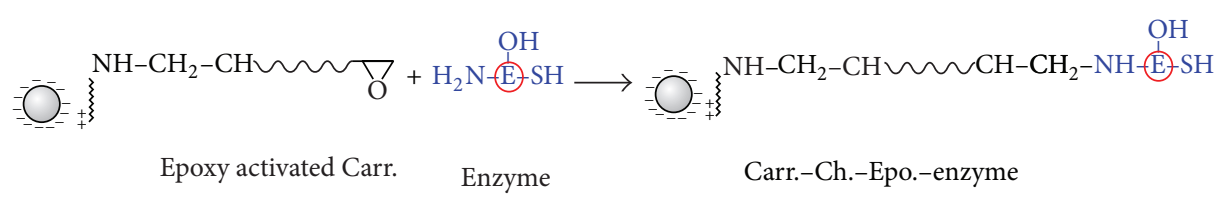

(c)

Scheme 1: Grafted carrageenan gel beads with epoxy groups and immobilization of enzymes. (a) Modification of carrageenan beads with chitosan via ionic interaction. (b) Incorporation of epoxy groups to the carrageenan-chitosan. (c) Immobilization of enzymes to the grafted carrageenan-epoxy via $-\mathrm{SH},-\mathrm{OH}$, or $-\mathrm{NH}_{2}$.

of free and immobilized $\beta$-galactosidase were determined for lactose using the Hanes-Woolf plot method. Free and immobilized $\beta$-galactosidases were incubated into $10 \mathrm{~mL}$ of 25 to $200 \mathrm{mM}$ at $37^{\circ} \mathrm{C}$ and $\mathrm{pH} 4.5$ for $3 \mathrm{hrs}$ under standard assay conditions.

2.8.3. Lactose Hydrolysis Using Immobilized $\beta$-Galactosidase. To evaluate the efficiency of the immobilized enzyme, it was used for lactose hydrolysis using the optimum conditions obtained from above optimization for the free and immobilized enzymes.

\section{Results and Discussion}

3.1. Grafted Alginate Elucidation Structure. Protonated amino groups $\left(-\mathrm{NH}_{3}{ }^{+}\right)$of $\mathrm{Ch}$ formed a polyelectrolyte complex with the $-\mathrm{OSO}_{3}{ }^{-}$of the Carr gel and incorporated free amino groups to Carr [19]. The free amino groups $\left(-\mathrm{NH}_{2}\right)$ of $\mathrm{Ch}$ were used to covalently immobilize $\beta$-galactosidase via the di-epoxy groups as a mediator beside its main role as a crosslinker. The enzyme could be bound to the carrier's free epoxy groups via its $-\mathrm{SH},-\mathrm{OH}$, and $-\mathrm{NH}$ groups. However, as shown in Scheme 1, we represented that one uses the free $\mathrm{NH}$ groups as an example to follow the $-\mathrm{OH}$ and $-\mathrm{SH}$ groups.

The FTIR bands of Carr; Carr-Ch; Carr-Ch-Epo.; CarrCh-Epo-Ch; Carr-Ch-Epo-Ch-Epo were shown in Figure 1. Spectrums of the three compounds, Carr; Carr-Ch; CarrCh-Epo, revealed a new and strong band at $870 \mathrm{~cm}^{-1}$, which appears only for the modified gel spectrum with epoxy groups. This band proved the presence of a new gel functional group, epoxy group, which is in agreement with the author's previous work [20]. This band disappeared after treatment

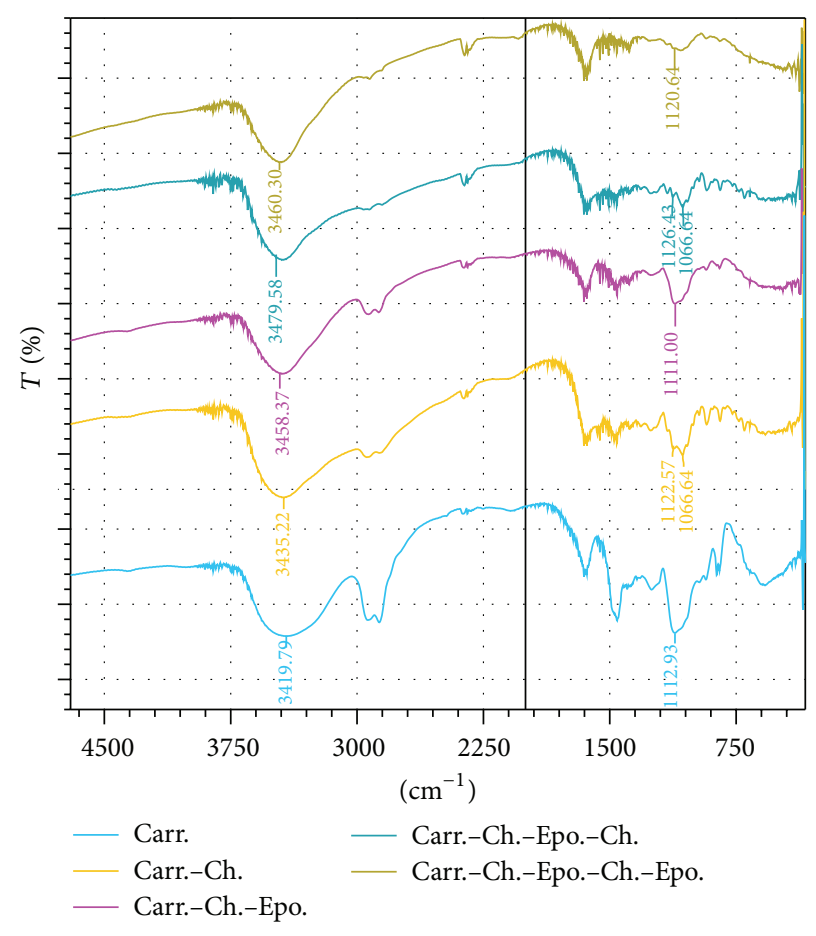

FIGURE 1: FTIR of five formulations of carrageenan and modified carrageenan with chitosan and epoxy groups: Carr; Carr-Ch; CarrCh-Epo; Carr-Ch-Epo-Ch; Carr-Ch-Epo-Ch-Epo.

of the Carr-Ch-Epo with $\mathrm{Ch}$ and reappeared after further treatment with epoxy (Carr-Ch-Epo-Ch-Epo) at $880 \mathrm{~cm}^{-1}$. The FTIR bands also revealed a decrease in intensity and a 
TABLE 1: Values of DSC and TGAA thermograms of carrageenan and modified carrageenan with chitosan and epoxy groups.

\begin{tabular}{lccc}
\hline Number & Formula & DSC temp, ${ }^{\circ} \mathrm{C}$ & TGA temp, ${ }^{\circ} \mathrm{C}$ \\
\hline 1 & Carr & 220 & 200 \\
2 & Carr-Ch & 230 & 210 \\
3 & Carr-Ch-Epo & $250 \& 320$ & 250 \\
4 & Carr-Ch-Epo-Ch & 260 & 240 \\
5 & Carr-Ch-Epo-Ch-Epo & $260 \& 330$ & 270 \\
\hline
\end{tabular}

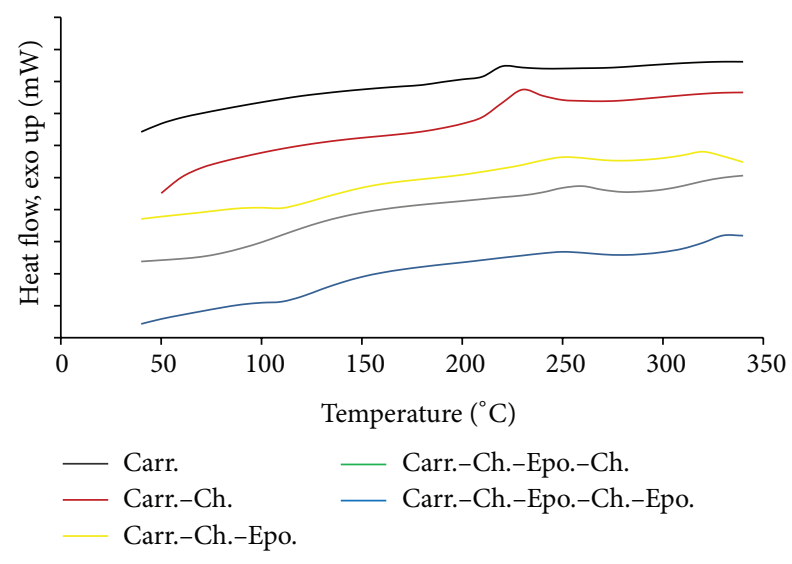

FIGURE 2: DSC thermogram of carrageenan and modified carrageenan with chitosan and epoxy groups.

shift of the $-\mathrm{OSO}_{3}{ }^{-}$absorption band of Carr from $1446 \mathrm{~cm}^{-1}$ to $1390 \mathrm{~cm}^{-1}$ after reaction with the chitosan. This ionic interaction between the carrageenan and the chitosan evidenced the formation of strong polyelectrolyte complexes [21].

Table 1 is tabulating the main characteristic values of the DSC and TGAA thermograms as shown in Figures 2 and 3, respectively.

The treatment of carrageenan with chitosan and epoxy has shown gradual and obvious improvement in their DSC and TGA. The DSC exothermic effect has been shifted to higher temperatures from formula numbers $1-5$, that is, from $220^{\circ} \mathrm{C}$ to $320^{\circ} \mathrm{C}$. The Carr has shown an exothermic band at $220^{\circ} \mathrm{C}$, which has been shifted to $230^{\circ} \mathrm{C}$ after treatment with $\mathrm{Ch}$. This improvement could be attributed to the formation of a complex network between the Carr and the Ch. Similar behavior has been attained when the di-epoxy has been substituted with glutaraldehyde [3]. Further treatment with di-epoxy, Carr-Ch-Epo, gradually increased the temperature to two peaks at 250 and $230^{\circ} \mathrm{C}$. This could be attributed to extra crosslinking with the di-epoxy and the two bands could be referred to the $\mathrm{Ch}$ and Epo; however, we could not tell at this stage which is which. However, by addition of $\mathrm{Ch}$, CarrCh-Epo-Ch, the temperature increased to a single band at $260^{\circ} \mathrm{C}$, which should be regarded to the $\mathrm{Ch}$. That means that for the short chain, Carr-Ch-Epo, the two peaks should be for $\mathrm{Ch}$ and Epo, respectively. Finally, by adding more di-epoxy, Carr-Ch-Epo-Ch-Epo (long chain), two bands appeared for

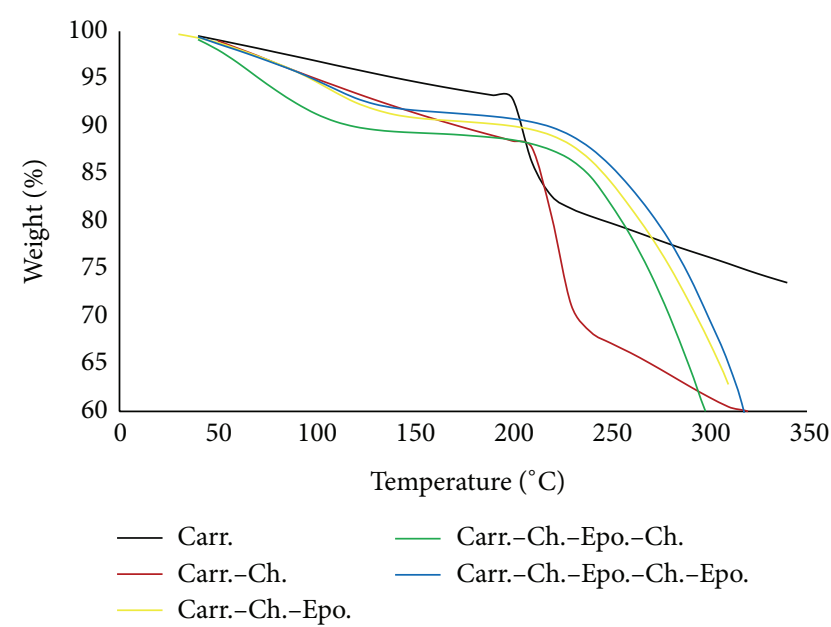

FIGURE 3: TGA thermogram of carrageenan and modified carrageenan with chitosan and epoxy groups.

the $\mathrm{Ch}$ and Epo at the highest temperatures, 260 and $330^{\circ} \mathrm{C}$, respectively.

On the other hand, the TGA of the modified Carr, formula numbers 2-5, showed a better stability against degradation as shown in Figure 3 and Table 1. For example, unmodified Carr had a sudden decomposition at $200^{\circ} \mathrm{C}$. This value has been increased to $210^{\circ} \mathrm{C}$ after its treatment with $\mathrm{Ch}$ with retention of the sudden decomposition behavior. The gels' thermal improvement could be explained by the formation of polyelectrolyte interaction between the polyanions $\left(-\mathrm{OSO}_{3}{ }^{-}\right)$ of the Carr and the polycations $\left(\mathrm{NH}_{3}{ }^{+}\right)$of the Ch. Further hardening of the gel beads using Epo showed a much higher increase in the TGAA Carr-Ch-Epo (short chain) to $250^{\circ} \mathrm{C}$ and the decomposition behavior was slower and gradual. The improvement in the TGA could be attributed to extra crosslinking between the free Ch's amino groups and the Epo. Further treatment of the short chain with $\mathrm{Ch}$ does not increase its TGA; however, it was more or less the same at $240^{\circ} \mathrm{C}$. Finally, for the long chain, Carr-Ch-Epo-Ch-Epo, the TGA increased to its maximum of $270^{\circ} \mathrm{C}$, which could be regarded to further crosslinking. It is worth noting that the short and long chains have the highest TGA values of 250 and $270^{\circ} \mathrm{C}$ with slower and gradual decomposition rate compared to other formulations.

3.2. Optimization of Enzyme's Loading Capacity. Two factors have been studied to optimize the loading capacity of $\beta$ galactosidases onto treated carrageenan gel beads.

3.2.1. Effect of Epoxy Chain Length. In this experiment short chain of epoxy modified gel beads, Carr-Ch-Epo, and long chain, Carr-Ch-Epo-Ch-Epo, were examined to assess chain length efficiency for immobilization of the enzyme. According to Sung and Bae, 2003 [22], the effect of the chain length could have a positive effect on the immobilization loading efficiency till certain length and then it declines afterwards. In our case, the short chain immobilized more enzymes than the long chain. Results as shown in Figure 4 showed that the short 


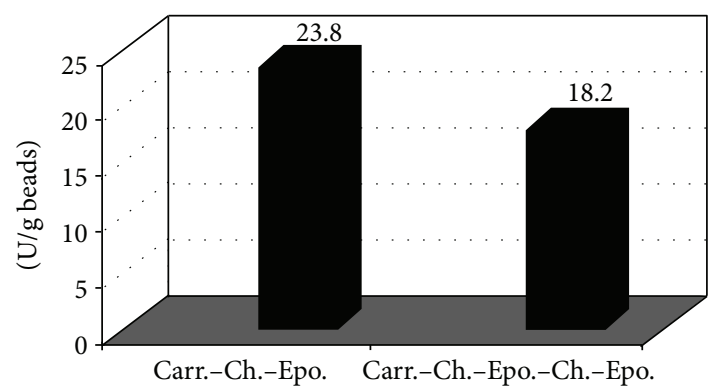

FIgURE 4: Effect of epoxy chain length on $\beta$-galactosidase loading capacity.

chain immobilized $23.8 \mathrm{U} / \mathrm{g}$ gel beds compared to $18.2 \mathrm{U} / \mathrm{g}$ gel beads for the long chain. These results are in accordance with that of Gancarz et al., 2003 [23], who observed that an increase in surface epoxy groups led to an increase in quantity of immobilized enzyme, but a decrease in retained enzyme activity.

To understand this phenomenon, we calculated from the supernatants the expected amounts of immobilized enzymes on the short and long chains formulas and they were found to be 18 and $21 \mathrm{U} / \mathrm{g}$, respectively. These results were in favor of the long chain formula; however, the retained activity of the immobilized enzymes was in favor of the short chain, where $23.8 \mathrm{U} / \mathrm{g}$ were immobilized, showing $133 \%$ retention of activity. This increase in the enzyme activity after immobilization could be regarded to the hydrogen bond interactions between the modified gel (polysaccharide) containing $-\mathrm{OH}$, $-\mathrm{OSO}_{3} \mathrm{H},-\mathrm{C}=\mathrm{O},-\mathrm{NH}_{2}$, and the lactose substrate containing $-\mathrm{OH},-\mathrm{C}=\mathrm{O}$ groups. These $\mathrm{H}$-bonding interactions could also increase the lactose concentration surrounding the gel surface more than the bulk solution and thus the activity of the immobilized enzyme increases till reaching saturation of the gel surface with lactase [24].

On the other hand, the long chain formulation was expected to immobilize $21 \mathrm{U} / \mathrm{g}$ and in practice it showed only $18.2 \mathrm{U} / \mathrm{g}$, which revealed $86 \%$ retention of activity of the immobilized enzyme. This could be regarded to the long chain having multipoint attachment or/and multilayers of the immobilized enzyme/steric hindrance that resulted in loss of the enzyme's 3D structure and consequently its activity. Accordingly, for further experiments, the short chain was used.

3.2.2. Effect of $\beta$-Galactosidase Concentration. $\beta$-Galactosidase was immobilized onto gel beads treated with short chain epoxy activated carrageenan, Carr-Ch-Epo, as shown in Figure 5.

Results revealed that by increasing the concentration of $\beta$-galactosidase from $10 \mathrm{U}$ to $60 \mathrm{U}$, the E.L.C. increased gradually till it reached its maximum of $36 \mathrm{U} / \mathrm{g}$ gel beads using $50 \mathrm{U}$ of free enzyme, after which any more added enzyme has almost no effect on the E.L.C. This could be regarded to all free epoxy groups that have been engaged with the enzymes [25]. However, we have chosen for further optimization the E.L.C. of $36 \mathrm{U} / \mathrm{g}$ gel beads as it shows better

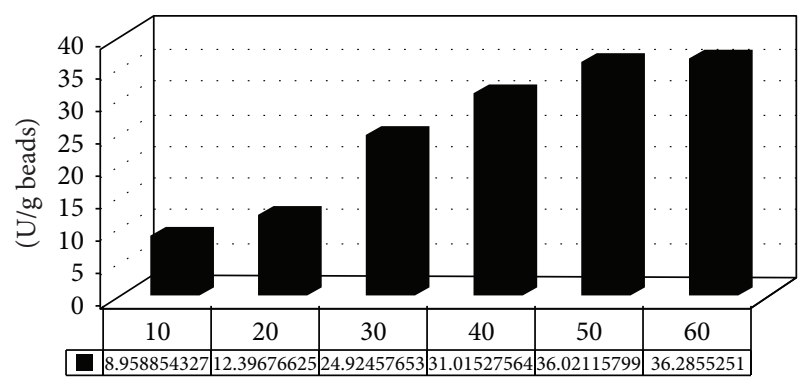

- (U/g)

FIGURE 5: $\mathrm{pH}$ profile of the free and immobilized $\beta$-galactosidase.

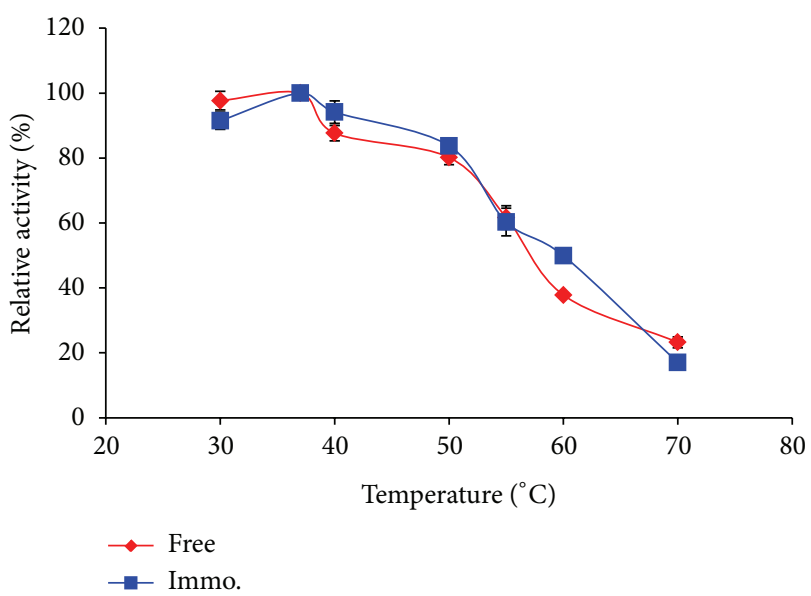

FIgURE 6: Michaelis constants of free and immobilized $\beta$ galactosidase.

enzyme loading efficiency of $49 \%$, which is more economic as it saves unloaded enzyme from being wasted.

\subsection{Evaluation of Catalytic Activity of Free and Immobilized} $\beta$-Galactosidase. At this stage, five experiments were studied. Firstly, the optimum reaction temperature, $\mathrm{pH}$, and substrate concentrations were examined for both the free and immobilized enzyme. Secondly, the best results from the first step were used to obtain the maximum substrate hydrolysis as well as the operational stability of the immobilized enzyme.

3.3.1. Optimum Temperature for the Free and Immobilized $\beta$ Galactosidase. The optimum temperature for the free and immobilized enzyme was examined. Results as shown in Figure 6 revealed that the optimum temperature for the immobilized enzyme was found to be at a slightly higher temperature $\left(37-40^{\circ} \mathrm{C}\right)$ compared to the free enzyme $(30-$ $\left.37^{\circ} \mathrm{C}\right)$.

The shift of the optimum temperature towards higher temperatures when the biocatalyst is immobilized indicates that the enzyme structure is strengthened by the immobilization process, and the formation of a molecular cage around the protein molecule (enzyme) was found to enhance the enzyme thermal stability. The increase of the immobilized 


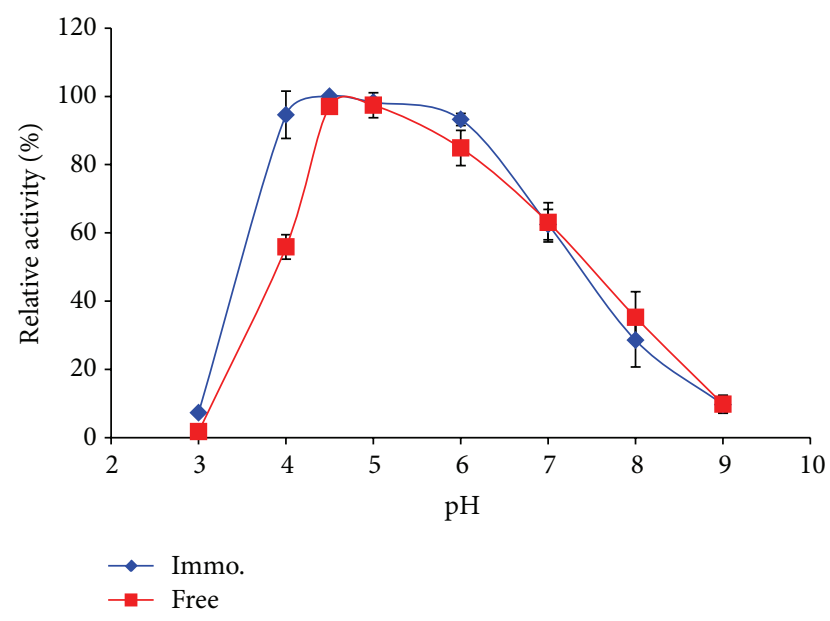

Figure 7: Lactose hydrolysis using free and immobilized $\beta$ galactosidase.

enzyme temperature tolerance may also be due to diffusional effects where the reaction velocity is more likely to be diffusion limited, so that improvements in thermal diffusion would correspondingly result in proportionally higher reaction rates [3].

3.3.2. $p H$ Profile. Figure 7 illustrates the $\mathrm{pH}$ activity profile of the free and immobilized $\beta$-galactosidase. The optimum $\mathrm{pH}$ values for free and immobilized enzyme were 4.5-5 and 46 , respectively, which showed that the immobilized enzyme was more stable at higher and wider range of $\mathrm{pH}$ [25]. These properties could be very useful for lactolysis in sweet whey permeate, which has a $\mathrm{pH}$ range of 5.5-6. Moreover, at $\mathrm{pH}$ 4 , the immobilized enzyme retained more than $95 \%$ of its relative activity compared to only $56 \%$ for the free enzyme.

The shift in the $\mathrm{pH}$ activity profile of the immobilized $\beta$ galactosidase and the better $\mathrm{pH}$ stability may be attributed to the partition effects that were arising from different concentrations of charged species in the microenvironment of the immobilized enzyme and in the domain of the bulk solution [3].

3.3.3. Determination of Kinetic Parameters of Free and Immobilized $\beta$-Galactosidase. The kinetic constants of free and immobilized $\beta$-galactosidase as shown in Figure 8 were tabulated in Table 2.

The apparent $K_{m}$ after immobilization, $131.4 \mathrm{mM}$, is higher than that of the free enzyme, $58.9 \mathrm{mM}$, which indicates that a higher concentration of substrate, 2-fold, is needed for the immobilized enzyme compared to the free enzyme. Nevertheless, higher $K_{m}$ values for immobilized $\beta$-galactosidase have been reported by other authors with increases from 1.2fold up to 5.4-fold [26]. These results are most likely due to the fact that the immobilized enzyme surfaces are not accessible to all the reacting species. However, no substrate or product inhibition by the increase of substrate concentration up to $200 \mathrm{mM}$ could be observed during our experiment, as

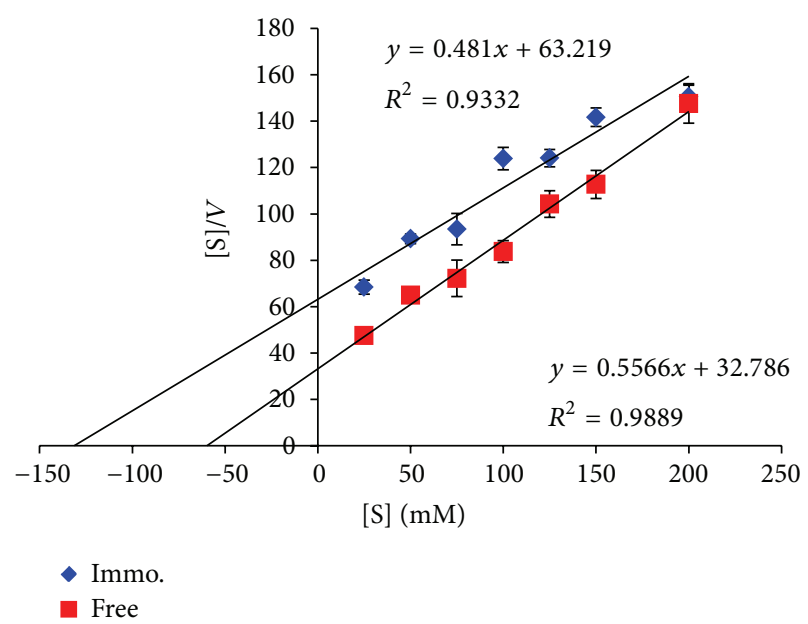

Figure 8: Reusability of the immobilized $\beta$-galactosidase.

TABLE 2: Michaelis-Menten constants and maximal reaction rate values for free and immobilized lactase.

\begin{tabular}{lcc}
\hline \multirow{2}{*}{$\beta$-Galactosidase form } & \multicolumn{2}{c}{ Kinetic constants } \\
& $K_{m}(\mathrm{mM})$ & $V_{\max }\left(\mu \mathrm{mol} \cdot \mathrm{min}^{-1}\right)$ \\
\hline Free & 58.9 & 32.7 \\
Immobilized & 131.4 & 63.2 \\
\hline
\end{tabular}

shown by the straight line of the Hanes-Wolf representation (Figure 8).

On the other hand, the maximum reaction velocity, $V_{\max }$, values for the immobilized enzyme were remarkable; it was found to double that of the free enzyme; that is, it increased from 32.7 to $63.2 \mu \mathrm{mol} \cdot \mathrm{min}^{-1}$. This result is in agreement with the speculation that the improvement in the immobilized enzyme thermal stability as in Section 3.3 .1 could result in a higher reaction velocity. It is worth noting that the increase in the reaction velocity is generally favored in industries.

3.3.4. Lactose Hydrolysis Using Free and Immobilized $\beta$ Galactosidase. This experiment has been carried out so that the immobilized enzyme could attain its maximum efficiency and act with its highest velocity using almost double the $K_{m}$ concentration of substrate and using the enzyme's optimum conditions. A high concentration of substrate, $200 \mathrm{mM}$, at $\mathrm{pH} 4.5$ and $37^{\circ} \mathrm{C}$, was used in this study, as this enzyme was supposed to be suitable for hydrolysis of higher lactose concentrations found in mammal milk (88-234 mM lactose) and whey permeate ( $85 \%$ lactose) [25].

The results as shown in Figure 9 revealed that for the first hour, the rate of conversion of the free enzyme was higher than that of the immobilized one. This could be attributed to the fact that the gel needed longer time to reach its maximum swelling. This swelling will allow more substrates to penetrate into the pores and consequently decrease the diffusion limitation. However, at $90 \mathrm{~min}$, both enzyme forms followed the same trend and the same speed till they reached maximum relative conversion at $120 \mathrm{~min}$. It is worth noting that at $90 \mathrm{~min}$, the gel beads carrying the enzyme reached its 


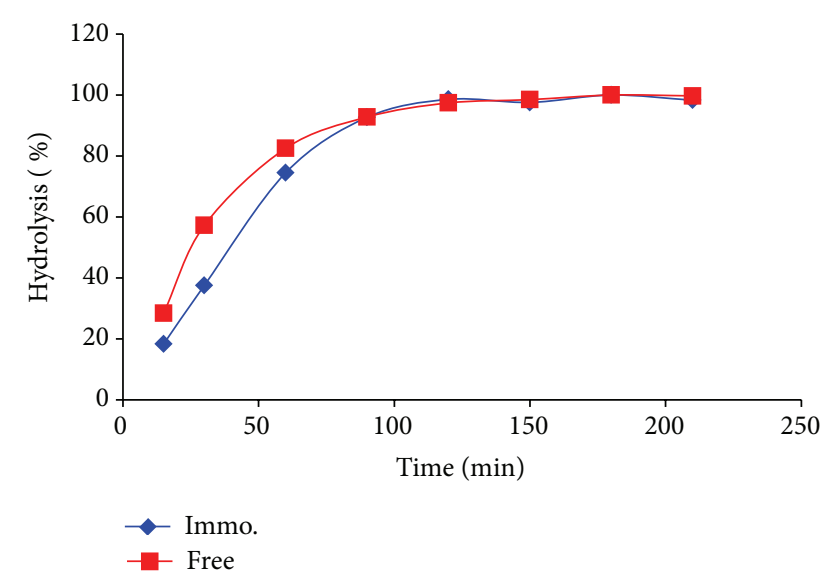

FIGURE 9: Effect of $\beta$-galactosidase concentration on the enzyme's loading capacity.

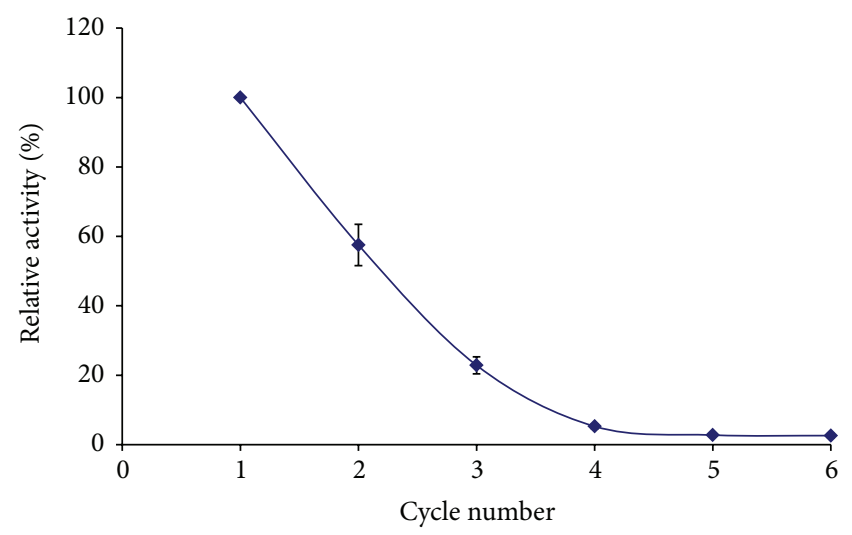

FIGURE 10: Temperature profile of free and immobilized enzyme.

maximum swelling, overcame its substrate/product diffusion limitation, and followed the same trend as the free enzyme, which is advantageous in industries. That means that the small gel beads used in this work could overcome the problem the authors previously had when they used big gel disks as the enzyme suffered from diffusion limitation and hydrolyzed only $63 \%$ of the free enzyme [3].

3.3.5. Reusability of Immobilized Enzyme. To evaluate the reusability of the immobilized enzyme, the beads were soaked in $200 \mathrm{mM}$ lactose for $120 \mathrm{~min}$ till full conversion of lactose to glucose and galactose. The gel beads were removed from the product, washed with buffer solution after use, and then resuspended in a fresh aliquot of a substrate to measure the enzymatic activity.

This procedure was repeated until the enzyme lost its activity. The turn over number of the enzyme catalyzed process was calculated. As shown in Figure 10, the immobilized enzyme retained $60 \%$ of its relative activity by the second use and $21 \%$ by the 3rd use. Nevertheless, these results were in agreement with those obtained by other authors using the commercial carrier, Novozym 435, as the immobilized activity decreased to $23 \%$ after the second use and to $3.7 \%$ by the third use [27]. The loss in activity was attributed by other authors to inactivation of enzyme due to continuous use [28]. Although our carrier has shown better performance than that of Novozyme 435, we think that the modified gel with epoxy could be further modified for future work.

\section{Conclusion}

Novel biopolymer based on epoxy activated carrageenan was prepared for immobilization of lactase as an example of medical enzyme. The results were compared to those of our previous work, using aldehyde activated carrageenan. The epoxy formula showed far better immobilization efficiency that was triple that shown using the aldehyde one. That could be regarded to that the epoxy group is more active than the aldehyde group. The aldehyde group could only bind to the enzyme's free amino groups, whereas the epoxy group could bind to three groups, $-\mathrm{SH},-\mathrm{NH}_{2}$, and $-\mathrm{OH}$. The results showed in Figure 9, hydrolysis of lactose, using free and immobilized lactase revealed that the immobilized enzyme could attain its maximum efficiency and act with its highest velocity as fast as the free enzyme. That was regarded to the gel beads carrying the enzyme that reached its maximum swelling and overcame its substrate/product diffusion limitation and followed the same trend as the free enzyme, which is advantageous in industries. The high activity of the epoxy formulation is highly recommended to be used for immobilization of other enzymes/proteins and/or drug delivery systems.

\section{Abbreviations \\ Carr: \\ Carr-Ch: \\ Carr-Ch-Epo: \\ Carr-Ch-Epo-Ch: \\ Carrageenan \\ Carrageenan-chitosan \\ Carrageenan-chitosan-epoxy \\ Carrageenan-chitosan-epoxy- chitosan \\ Carr-Ch-Epo-Ch-Epo: Carrageenan-chitosan-epoxy- chitosan-epoxy.}

\section{Conflict of Interests}

The authors declare that there is no conflict of interests regarding the publication of this paper.

\section{References}

[1] Q. Husain, " $\beta$-Galactosidases and their potential applications: a review," Critical Reviews in Biotechnology, vol. 30, no. 1, pp. 4162, 2010.

[2] M. M. Elnashar, G. E. Awad, M. E. Hassan, M. S. Mohy Eldin, B. M. Haroun, and A. I. El-Diwany, "Optimal immobilization of $\beta$-galactosidase onto $\kappa$-Carrageenan gel beads using response surface methodology and its applications," The Scientific World Journal, vol. 2014, Article ID 571682, 7 pages, 2014.

[3] M. M. M. Elnashar and M. A. Yassin, "Lactose hydrolysis by $\beta$-galactosidase covalently immobilized to thermally stable biopolymers," Applied Biochemistry and Biotechnology, vol. 159, no. 2, pp. 426-437, 2009. 
[4] G. F. Bickerstaf, "Impact of genetic technology on enzyme technology," The Genetic Engineer and Biotechnologist, vol. 15, pp. 13-30, 1995.

[5] M. M. Elnashar, "The art of immobilization using biopolymers, biomaterials and nanobiotechnology," in Biotechnology of Biopolymers, pp. 1-30, Intech, 2011.

[6] G. Roberts, "Structure of chitin and chitosan," in Chitin Chemistry, G. A. F. Roberts, Ed., pp. 1-53, MacMillan, Houndmills, UK, 1992

[7] R. Hejazi and M. Amiji, "Chitosan-based gastrointestinal delivery systems," Journal of Controlled Release, vol. 89, no. 2, pp. 151165, 2003.

[8] B. Krajewska, "Application of chitin- and chitosan-based materials for enzyme immobilizations: a review," Enzyme and Microbial Technology, vol. 35, no. 2-3, pp. 126-139, 2004.

[9] M. M. Elnashar, O. A. Ali, and H. A. Ragaa, "Immobilized penicillin $\mathrm{G}$ acylase onto grafted k-carrageenan: hypothesis on the effect of $\mathrm{pH}$ on the gel-enzyme interaction," Arabian Journal of Chemistry. In press.

[10] K. C. Chao, M. M. Haugen, and G. P. Royer, "Stabilization of kappa-carrageenan gel with polymeric amines: use of immobilized cells as biocatalysts at elevated temperatures," Biotechnology and Bioengineering, vol. 28, no. 9, pp. 1289-1293, 1986.

[11] J. S. Chang, C. Chou, and S. Y. Chen, "Decolorization of azo dyes with immobilized Pseudomonas luteola," Process Biochemistry, vol. 36, no. 8-9, pp. 757-763, 2001.

[12] S. H. Moon and S. J. Parulekar, "Characterization of $\kappa$ carrageenan gels used for immobilization of Bacillus firmus," Biotechnology Progress, vol. 7, no. 6, pp. 516-525, 1991.

[13] E. N. Danial, M. M. M. Elnashar, and G. E. A. Awad, "Immobilized inulinase on grafted alginate beads prepared by the onestep and the two-steps methods," Industrial and Engineering Chemistry Research, vol. 49, no. 7, pp. 3120-3125, 2010.

[14] D. K. Boadi and R. J. Neufeld, "Encapsulation of tannase for the hydrolysis of tea tannins," Enzyme and Microbial Technology, vol. 28, no. 7-8, pp. 590-595, 2001.

[15] A. M. Eberhardt, V. Pedroni, M. Volpe, and M. L. Ferreira, "Immobilization of catalase from Aspergillus niger on inorganic and biopolymeric supports for $\mathrm{H}_{2} \mathrm{O}_{2}$ decomposition," Applied Catalysis B: Environmental, vol. 47, no. 3, pp. 153-163, 2004.

[16] M. M. Elnashar, "Review article: immobilized molecules using biomaterials and nanobiotechnology," Journal of Biomaterials and Nanobiotechnology, vol. 1, pp. 61-76, 2010.

[17] E. Magnan, I. Catarino, D. Paolucci-Jeanjean, L. Preziosi-Belloy, and M. P. Belleville, "Immobilization of lipase on a ceramic membrane: activity and stability," Journal of Membrane Science, vol. 241, no. 1, pp. 161-166, 2004.

[18] S. Rocchietti, A. S. V. Urrutia, M. Pregnolato et al., "Influence of the enzyme derivative preparation and substrate structure on the enantioselectivity of penicillin G acylase," Enzyme and Microbial Technology, vol. 31, no. 1-2, pp. 88-93, 2002.

[19] M. M. M. Elnashar and M. A. Yassin, "Covalent immobilization of $\beta$-galactosidase on carrageenan coated with chitosan," Journal of Applied Polymer Science, vol. 114, no. 1, pp. 17-24, 2009.

[20] A. A. El-Sanabary, M. M. Elnashar, A. A. Magda, and B. M. Badran, "Preparation and evaluation of some new corrosion inhibitors in varnishes," Anti-Corrosion Methods and Materials, vol. 48, no. 1, pp. 47-58, 2001.

[21] C. Tapia, Z. Escobar, E. Costa et al., "Comparative studies on polyelectrolyte complexes and mixtures of chitosan-alginate and chitosan-carrageenan as prolonged diltiazem clorhydrate release systems," European Journal of Pharmaceutics and Biopharmaceutics, vol. 57, no. 1, pp. 65-75, 2004.

[22] W. J. Sung and Y. H. Bae, "A glucose oxidase electrode based on polypyrrole with polyanion/PEG/enzyme conjugate dopant," Biosensors and Bioelectronics, vol. 18, no. 10, pp. 1231-1239, 2003.

[23] I. Gancarz, J. Bryjak, M. Bryjak, G. Poźniak, and W. Tylus, "Plasma modified polymers as a support for enzyme immobilization 1. Allyl alcohol plasma," European Polymer Journal, vol. 39, no. 8, pp. 1615-1622, 2003.

[24] M. M. M. Elnashar, M. A. Yassin, and T. Kahil, "Novel thermally and mechanically stable hydrogel for enzyme immobilization of penicillin G acylase via covalent technique," Journal of Applied Polymer Science, vol. 109, no. 6, pp. 4105-4111, 2008.

[25] A. Tanriseven and Ş. Doğan, "A novel method for the immobilization of $\beta$-galactosidase," Process Biochemistry, vol. 38, no. 1, pp. 27-30, 2002.

[26] Q. Z. K. Zhou and X. Dong Chen, "Immobilization of $\beta$ galactosidase on graphite surface by glutaraldehyde," Journal of Food Engineering, vol. 48, no. 1, pp. 69-74, 2001.

[27] B. Chen, J. Hu, E. M. Miller, W. Xie, M. Cai, and R. A. Gross, "Candida antarctica Lipase B chemically immobilized on epoxy-activated micro- and nanobeads: catalysts for polyester synthesis," Biomacromolecules, vol. 9, no. 2, pp. 463-471, 2008.

[28] K. Nakane, T. Ogihara, N. Ogata, and Y. Kurokawa, "Entrapimmobilization of invertase on composite gel fiber of cellulose acetate and zirconium alkoxide by sol-gel process," Journal of Applied Polymer Science, vol. 81, no. 9, pp. 2084-2088, 2001. 

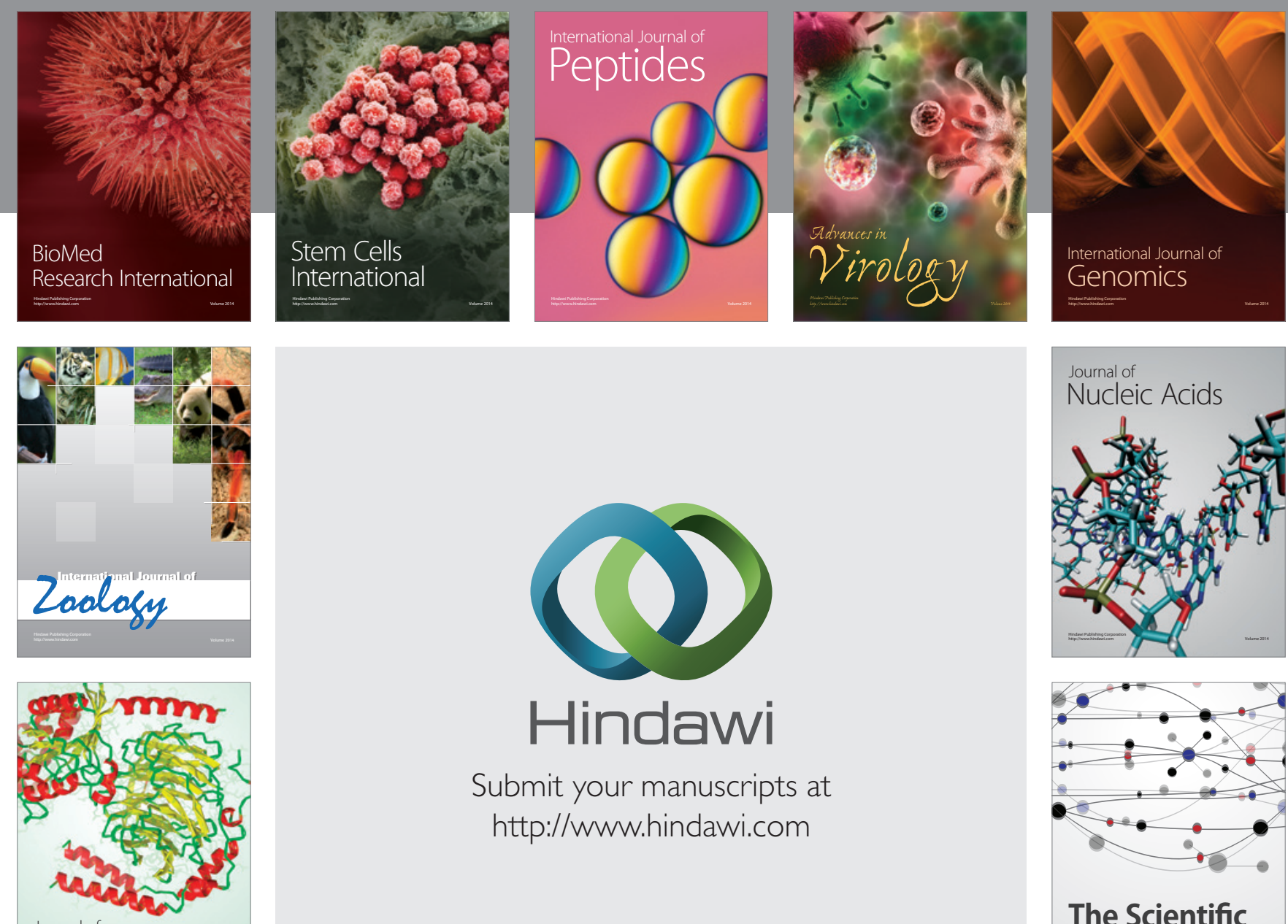

Submit your manuscripts at

http://www.hindawi.com

Journal of
Signal Transduction
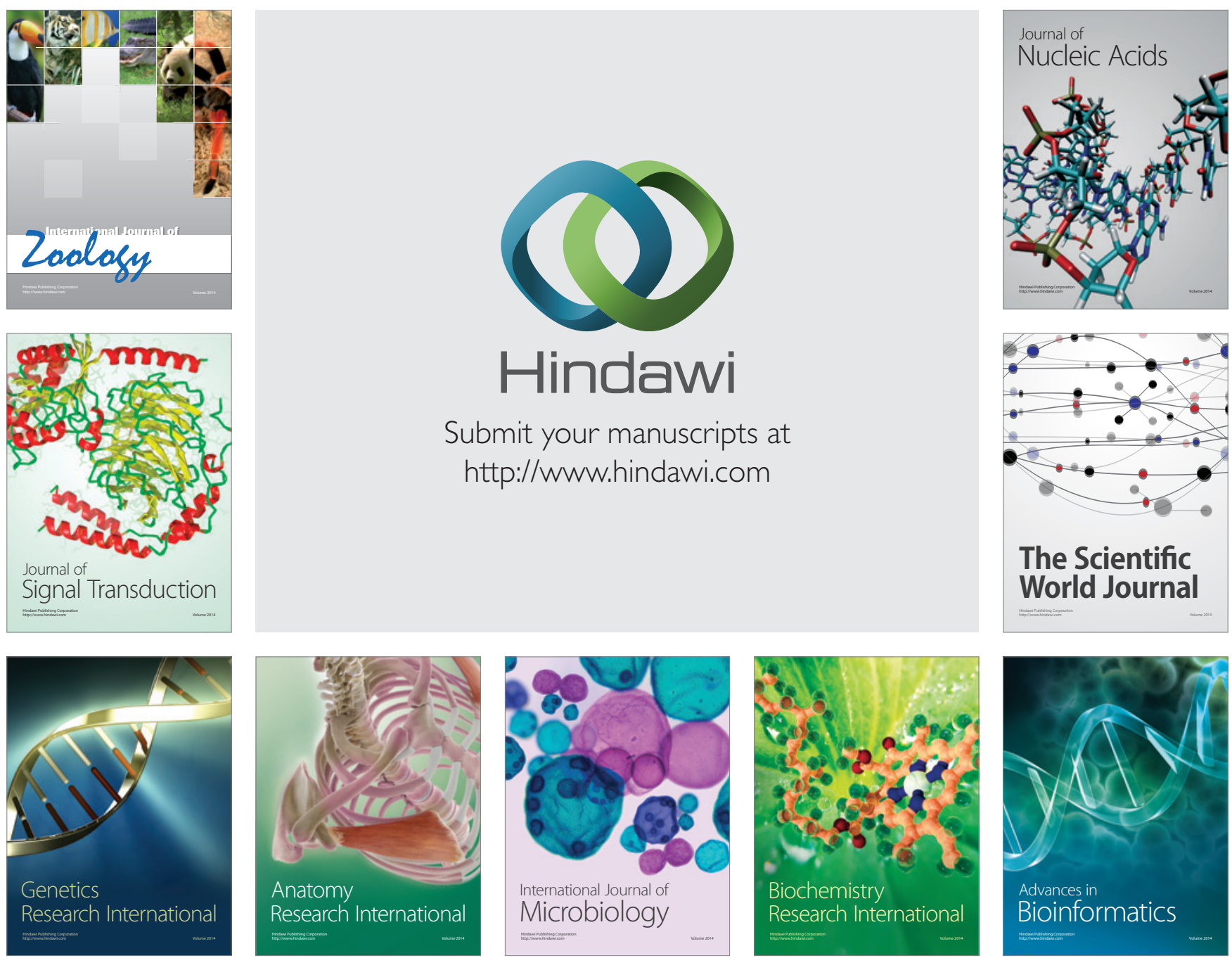

The Scientific World Journal
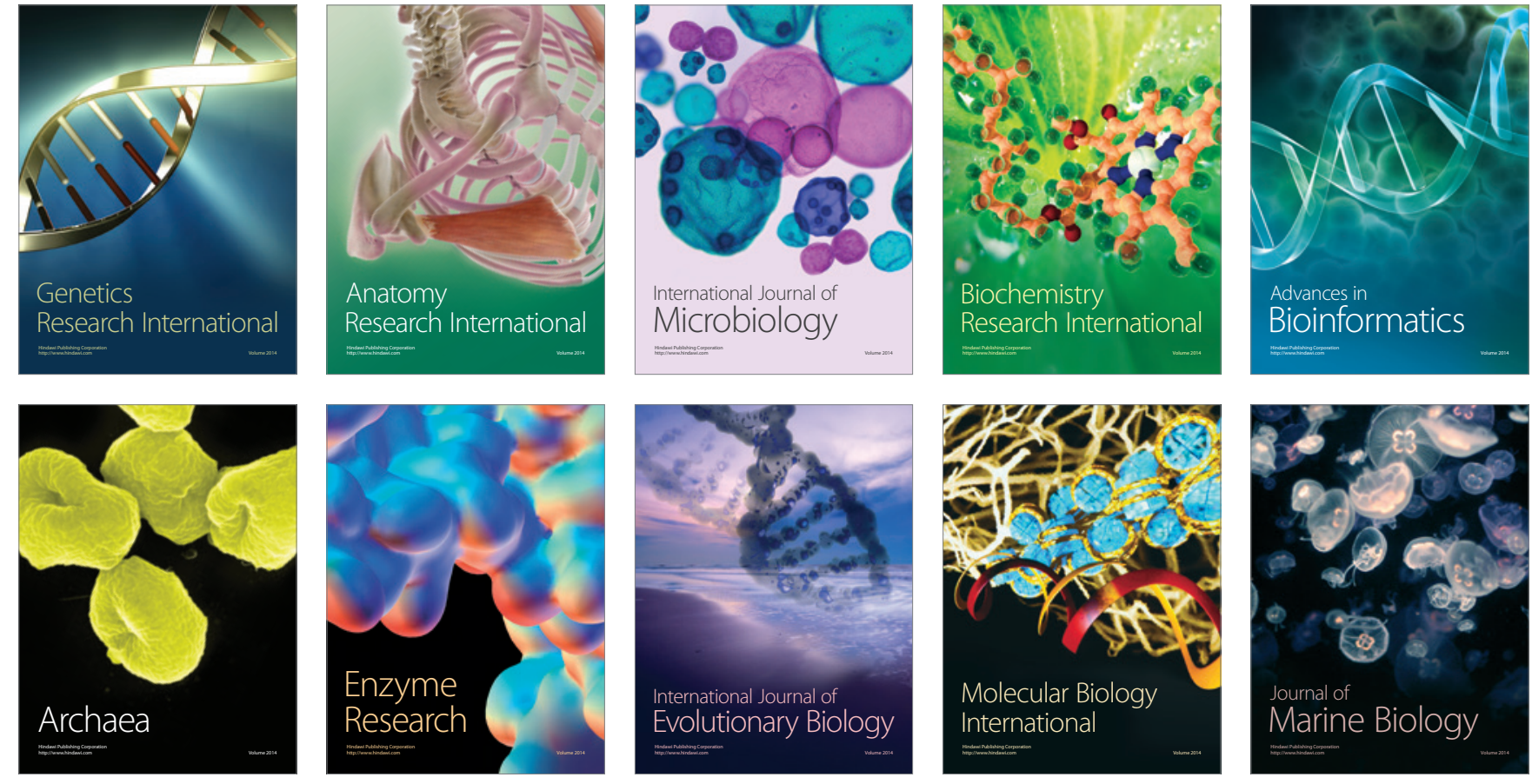